\title{
JEDENASTOWIECZNE ECHO SPORU O TYTUt PATRIARCHY EKUMENICZNEGO
}

Konflikt wokół nazywania patriarchów Konstantynopola ekumenicznymi był związany ze wzrostem rangi biskupstwa konstantynopolitańskiego i z wynikającym z niego sporem o prymat w Kościele między biskupami Starego i Nowego Rzymu ${ }^{1}$. Za jego początek uznać można rok 483, gdy papież Feliks III oskarżył patriarchę Akacjusza o dążenie do podporządkowania sobie całego Kościoła ${ }^{2}$. Jednak główny etap konfliktu rozegrał się na przełomie VI i VII w., za pontyfikatów Pelegiusza II (579-590) i Grzegorza Wielkiego (590-604). Właśnie wówczas pojawiła się tendencja, by zawęzić stosowanie tytułu „pa-

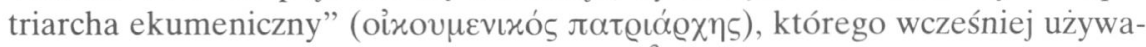
no sporadycznie wobec różnych biskupów ${ }^{3}$, wyłącznie do zasiadających na

${ }^{1}$ Problem ten był przedmiotem mojego artykułu: T. Wolińska, Spór o tytuł patriarchy ekumenicznego pomiędzy papieżem Grzegorzem Wielkim a biskupami Konstantynopola w świetle walki o prymat w Kościele powszechnym, „Acta Universitatis LodziensiFolia Historica” 48 (1993) 95-126; zob. także A. Tuilier, Grégoire le Grand et le titre de patriarche oecuménique, w: Grégoire le Grand. Colloques Internationaux du CNRS (Chantilly, 15-19 IX 1982), ed. J. FontaineR. Gillet, Paris 1986, 69-81; S. Vailhé, Saint Grégoire le Grand et le titre de patriarche oecuménique, EO 11 (1908) 161-171. W cytowanych artykułach czytelnik znajdzie odniesienia do dalszej literatury, np. V. Grummel, Les préliminaires du schisme de Michel Célulaire ou la question romaine avant 1054, REB 10 (1952) 5-23.

${ }^{2}$ Por. Maxime de Sardes, Le patriarchat oecumenique dans l'Eglise orthodoxe, Paris 1975, 312. Jednak chociaż papież zarzucał Akacjuszowi, że chce władzy nad całym Kościołem (zob. Felix III papa, Epistolae et decreta: Ep. 1, PL 58,898), nie oskarżył go wprost o posługiwanie się spornym tytułem. Przyjmuje się często, że po raz pierwszy tytuł „patriarcha ekumeniczny” został użyty w 518 r., por. H. Gelzer, Der Streit über den Titel ökumenischen Patriarchen, „Jahrbücher für protestantische Theologie" 13 (1887) 568; V. Laurent, Le titre du patriarche oecuménique et la signature patriarcale, REB 6 (1948) 8-9; Ch.D. du Cange, Glossarium mediae et infimae latinitatis, VI, Paris 1938, 31. Jednak P. Batiffol (Cathedra Petri. Etudes d'histoire ancienne de l'Eglise, Paris 1938, 204) datuje spór od czasów patriarchy Akacjusza.

${ }^{3}$ Nazywano tak między innymi Dioskura, biskupa Aleksandrii (zob. Mansi VI 855), papieża Leona Wielkiego (Mansi VI 1005, 1012, 1021, 1029), patriarchów Konstantynopola Jana II, Epifaniusza, Anthimosa, Menasa i innych (Mansi VIII 1038, 1042, 1058, 1059, 1094, 1066, 1067; Corpus Iuris Civilis [dalej: CIC], t. 2: Codex Justinianus I 1, 7; I 4, 34; CIC, t. 3: Novellae, Nov. 3, 5, 6, 16, 42, 
tronach Rzymu i Konstantynopola ${ }^{4}$. Nie ma potrzeby przedstawiania przebiegu konfliktu w niniejszym artykule. Warto natomiast przypomnieć podstawowe kwestie terminologiczne.

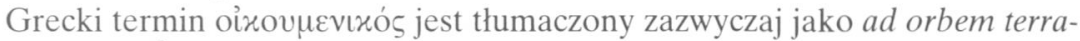

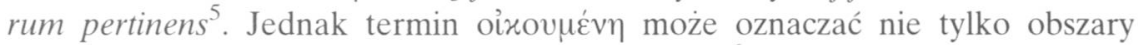
zamieszkane, ziemię, ale także państwo rzymskie ${ }^{6}$. W takim przypadku tytuł „patriarcha ekumeniczny” oznaczałby po prostu pierwszego rangą biskupa cesarstwa, nie dążącego wszakże do władzy nad całym Kościołem. Jak się wydaje, tak właśnie rozumowano na Wschodzie w VI wieku ${ }^{7}$. Nie oznacza to jednak, że aspiracje patriarchów nie niosły ze sobą pewnego zagrożenia pozycji Rzymu, który był wszak wówczas częścią cesarstwa ${ }^{8}$. Na Zachodzie jeszcze wyolbrzymiono niebezpieczeństwo, tłumacząc sporny tytuł jako episcopus solus ${ }^{9}$, universalis ${ }^{10}$. W ślad za takim przekładem szło przekonanie, iż biskupi Konstantynopola pragną władzy nad całym Kościołem, że chcą go sobie podporządkować ${ }^{11}$.

Wysiłki papieży, szczególnie Grzegorza Wielkiego, by zmusić patriarchów stolicy cesarstwa do zaniechania używania tytułu ekumenicznych, nie przyniosły zadowalających rezultatów. Jednym z zasadniczych powodów niepowodzenia był fakt, iż patriarchów Konstantynopola poparli cesarze, którzy nie widzieli powodu, by obawiać się wzrostu ich pozycji. Biskupi Konstantynopola lepiej rozumieli potrzeby państwa, niż papież. W znakomitej większości wypadków byli lojalni wobec panujących i pomagali im realizować wyznaczone cele polityczne. Byli doradcami, a często przyjaciółmi cesarzy, którym w znacznej mierze zawdzięczali swą karierę. Ponadto władcy byli zainteresowani zrównaniem swej nowej stolicy ze starym Rzymem, bo zaspokajało to także ich ambicje. Prowadząc politykę uniwersalistyczną w pełnym tego słowa znaczeniu, uważali za całkowicie naturalne, iż biskupi ich miasta noszą tytuł „powszechnych".

Wprawdzie po obaleniu Maurycjusza (602) jego następca Fokas w 607 r. potwierdził prymat biskupa Rzymu (był nim wówczas Bonifacjusz), ale naj-

55-57). Na temat historii użycia tego spornego tytułu por. F. Dvornik, Bizancjum a prymat Rzymu, tłum. M. Radożycka, Warszawa 1985, 58-59; Wolińska, Spór, s. 103.

${ }^{4}$ Por. Tuilier, Grégoire, s. 72.

5 Por. H. Stephanus, Thesaurus Graecae Linguae, V, Paris 1842-1846, kol. 1798.

${ }^{6}$ Por. Stownik grecko-polski, red. Z. Abramowiczówna, III, Warszawa 1962, 251. Szerzej na

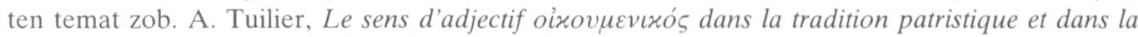
tradition byzantine, StPatr 7 (1966) 413-424.

7 Por. Dvornik, Bizancjum, s. 58-59.

${ }^{8}$ Por. Fliche-Martin V 64-65; N. Cheetcham, Keepers of the KeyThe Pope History, London 1982, 42; S. Vailhé, Constantinople (Eglise de), DThC III 1335; Wolińska, Spór, s. 104, nota 70.

${ }^{9}$ Por. Gregorius Magnus, Epistolae V 39; V 44.

${ }^{10}$ Por. tamże V 44.

11 Por. tamże, CCL 140, 334: „despectis fratribus, episcopus appetas solus vocari [...] non solum pater, sed etiam generalis pater in mundo vocari appetis". 
prawdopodobniej było to jedynie powtórzenie decyzji zawartych w prawodawstwie Justyniana $\mathrm{I}^{12}$. Jeśli nawet Fokas zakazał używania tytułu patriarchy ekumenicznego Cyriakowi ${ }^{13}$, to nie miało to wpływu na aspiracje następców tego ostatniego.

Papież nie znalazł też zrozumienia i poparcia u większości biskupów wschodniej części cesarstwa, włączając w to patriarchów Aleksandrii, Antiochii i Jerozolimy ${ }^{14}$. Na Wschodzie używanie spornego tytułu miało długą tradycję i nie upatrywano w nim naruszenia porządku kościelnego. Biskupi wschodni byli w znacznie mniejszym stopniu niż papież zaniepokojeni wzrostem roli patriarchy stolicy cesarstwa. Co więcej, upatrywali w nim swego sojusznika w walce z herezją i pośrednika w kontaktach z dworem cesarskim. Nie jest sprawą przypadku, iż tytuł ,patriarcha ekumeniczny” pojawiał się najczęściej w aktach synodalnych, prawodawstwie cesarskim i listach adresowanych przez biskupów ze Wschodu do patriarchy Konstantynopola ${ }^{15}$.

Spór o prymat i jego zakres trwał przez kolejne stulecia ${ }^{16}$, ale kwestii tytułu patriarchy ekumenicznego we wzajemnych relacjach w zasadzie nie

12 Por. Liber pontificalis, ed. L. Duchesne, Paris 1955, 316; Wśród uczonych trwa spór dotyczący charakteru tego rozporządzenia, zob. J. Herrin, Constantinople, Rome and the Franks in the seventh and eight centuries, w: Byzantine Diplomacy, ed. J. Shepard - S. Franklin, London 1992, 91; C. Lagier, L'Orient Chrétien, I, Paris 1935, 317; E.W. Morggraff, Sancti Gregorii Magni Vita, Berolini (bez daty wyd.), s. 40; R.P.J. Pargoire, L'Église byzantine de 527 à 847, Paris 1923, 5051; Tuilier, Grégoire, 70; G. Zanarini, Histoire de l'Église byzantin, Paris 1924, 141.

${ }^{13}$ Fokas nie miał powodu, by darzyć sympatią patriarchę Cyriaka, związanego z rodziną poprzedniego cesarza. Równocześnie zależało mu na poparciu papieża.

${ }^{14}$ Por. Zanarini, Histoire, s. 141; T. Uspienskij, Cerkovnopoliticeskaja dejatelnost' papy Grigorija I Dvojeslova, Kazań 1901, 217 i 221. Papież Grzegorz Wielki próbował wykorzystać rywalizację o prymat między wschodnimi patriarchatami (Ep. V 41, VII 31; VII 37 i in.). Jednak w jego czasach biskupi wschodni nie mogli i nie chcieli narażać się patriarsze Konstantynopola. Anastazjusz, patriarcha Antiochii, był w szczególnie trudnej sytuacji. Jego pozycja była osłabiona ze względu na rozwój herezji w jego patriarchacie. Potrzebował wsparcia Konstantynopola w jej zwalczaniu. Dlatego zdecydowanie stanął po stronie patriarchy Konstantynopola. Na prośbę cesarza napisał do Grzegorza, wyjaśniając mu, jak na Wschodzie rozumie się sporny tytuł (Ep. VII 24). Przychylniej do prośby Grzegorza odniósł się patriarcha Aleksandrii. Jednak czasy, w których biskupi aleksandryjscy intrygowali przeciw swym kolegom ze stolicy cesarstwa, a nawet doprowadzali do ich usunięcia z tronów, należały już do przeszłości. Eulogiusz wprawdzie po kolejnym liście papieża zaprzestał nazywania patriarchy Konstantynopola (był nim wówczas Cyriak) ekumenicznym, a nawet nazwał biskupem powszechnym samego Grzegorza (Ep. VIII 29), ale nic więcej nie chciał i nie mógł uczynić. Szerzej na ten temat zob. Wolińska, Spór, s. 114- 121.

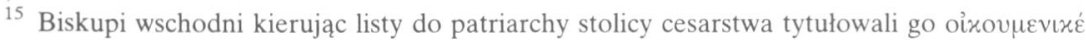

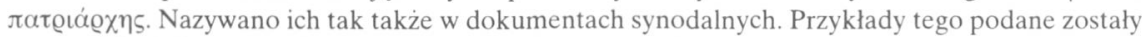
w przypisie 4. Dodajmy, że Jan Postnik w zachowanych pismach nie używa wspomnianego tytułu, jest natomiast tak nazywany przez inne osoby (Andreeff, s. 275; J. Czuj, Papież Grzegorz Wielki, Warszawa 1948, 173; Maxime de Sardes, Le patriarchat, s. 333).

16 Szerzej zob. Dvornik, Bizancjum, s. 61-96; K. Schatz, K. Schatz, Prymat papieski od początków do wspótczesności, thum. E. Marszał - J. Zakrzewski, Kraków 2004, 73-119. Warto 
poruszano. Dopiero na początku XI wieku, w przededniu schizmy wschodniej, problem powrócił raz jeszcze. Informacje na ten temat znajdujemy w tekście zachodniego kronikarza, Rodulfa Glabera ${ }^{17}$. Przyjrzyjmy się więc najpierw jego relacji.

Glaber zanotował, iż ok. 1024 r. przybyło do Rzymu poselstwo z Konstantynopola $z$ licznymi i bogatymi darami dla papieża ${ }^{18}$. Zostało ono przyjęte przez Jana XIX, któremu przedstawiło zaskakujące żądanie: patriarcha Konstantynopola, którym był wówczas Eustacjusz (1020-1025), cesarz Bazyli (mowa o Bazylim II Bułgarobójcy) i inni Grecy uznali, iż Kościołowi konstantynopolitańskiemu winien przysługiwać tytuł „uniwersalnego” na obszarze mu podległym (in suo orbe ${ }^{19}$ ), podobnie, jak Rzymowi w świecie (in universo) ${ }^{20}$. W ich opinii, na taki przywilej swą zgodę winien wyrazić papież ${ }^{21}$. Jej uzyskanie, jak wynika z relacji, miało być głównym powodem przysłania poselstwa. Oprócz darów dla papieża delegacja przywiozła też podarunki dla innych osób, które chciano sobie pozyskać. Kronikarz cytuje w związku z tym dawne przysłowie: aureo pugillo murum frangere ferrum ${ }^{22}$. Podkreśla jednak, że w Rzymie bizantyńskie złoto nie przyniosło spodziewanego efektu.

Relacja Rodulfa budzi szereg wątpliwości, poczynając od tego, czy w ogóle jakiekolwiek poselstwo zostało wysłane przez Bazylego II do Rzymu. Poza Rodulfem Glaberem wspomina o nim jedynie Hugon z Flavigny ${ }^{23}$. Kronikarz ten zaczerpnął informacje właśnie od Glabera, z którego tekstu korzystał ${ }^{24}$.

też sięgnąć po artykuły wydane w tomie: Il primato del vescovo di Roma nel primo millenio. Ricerche e testimonianze. Atti del symposium storico-teologico (Roma 9-13 X 1989), red. M. Maccarone, Città di Vaticano 1991. Dla interesującego nas okresu szczególnie ważne są teksty M. Maccarone, ,, Sedes apostolica - vicarius Christi. La perpetuità del primato di Pietro nella sede e nel vescovo di Roma (sec. III-VIII), tamże, s. 275-362 i D. Stiernon, Interprétations, résistances et oppositions en Orient, tamże, s. 61-705. Obszerną bibliografię na ten temat por. S. Longosz, Papiestwo w starożytności chrześcijańskiej, VoxP 24 (2004) t. 46-47, 693-704.

17 Por. Rodolfo il Glabo, Cronache dell'anno mille (Storie), ed. et transl. G. Cavallo G. Orlandi, Milano 2001 [dalej: Glaber, Cronache]. O kronikarzu i jego dziele zob. L. Petit, Raoul Glaber, „Revue historique” 48 (1892) 283-299; G. Cavallo, Introduzione, w: Glaber, Cronache, s. IX-XLIX. Rodulf był mnichem benedyktyńskim. Przebywał m.in. w klasztorach w Dijon i Cluny. Nie mial zbyt dobrej opinii ani jako mnich, ani jako dziejopis, por. W.P. Ker, Wczesne średniowiecze. Zarys historii literatury, Wrocław 1987, 155-156.

18 Por. Glaber, Cronache IV I, 2; V. Grumel, Les regestes des actes de patriarcat de Constantinople, vol. 1: Les actes des patriarchates, fasc. 2: Les regestes de 715 à 1043, Paris 1936, nr 828, 245.

${ }^{19}$ Por. Glaber, Cronache IV I, 2.

20 Por tamze.

${ }^{21}$ Por. tamże: „,cum consensu Romani pontificis, licet ecclesiam Constantinopolitanam [...] universalem dici et haberi”.

22 Por. tamże.

23 Por. Chronicon Virdunense II 17, MGH Scriptores VIII 392. Dysponujemy też wydaniem J.P. Migne'a: Hugonis Flaviniacensis Chronicon, PL 154, 240-241.

${ }^{24}$ Por. F. Dvornik, Constantinople and Rome, w: The Cambridge Medieval History, IV, Cambridge 1966, 460. 
Brak potwierdzenia poselstwa przez inne, niezależne źródło, sprawia, iż niektórzy uczeni kwestionują jego realność ${ }^{25}$. Innego zdania są między innymi Francis Dvornik i Gilbert Dagron. Pierwszy z wymienionych uważa za prawdopodobne, iż cesarz starał się zakończyć spór między obu Kościołami ${ }^{26}$. Z kolei Gilbert Dagron sądzi, iz cesarz i patriarcha zabiegali o uzyskanie od Rzymu większej autonomii w sprawach religijnych ${ }^{27}$. Niezbędne jest więc bliższe przyjrzenie się temu problemowi.

Bazyli II był w 1024 r. u szczytu potęgi. Po zwycięstwie nad Bułgarami i podporządkowaniu Serbii przymierzał się do planów wzmocnienia pozycji Bizancjum na Bałkanach i podjęcia próby odzyskania Sycylii z rąk muzułmanów ${ }^{28}$. Plan cesarza polegał na zabezpieczeniu sobie bazy apulijsko-kalabryjskiej, która miała stać się punktem wypadowym na Sycylię ${ }^{29}$. Już w 992 r. zapewnił sobie pomoc floty weneckiej $\mathrm{w}$ transporcie wojsk bizantyńskich do południowej Italii ${ }^{30}$. Według kronikarza z Bari, Bizantyńczycy już wtedy przygotowywali inwazję na wyspę ${ }^{31}$.

Do planów, których wówczas nie udało się zrealizować, wrócono po kilkudziesięciu latach. W 1018 r. katepan Bazyli Boioannes podporządkowal cesarstwu Kapuę, Benewent i Salerno ${ }^{32}$. Był to wstęp do dużej akcji na Zachodzie. Na krótko przed śmiercią Bazyli II przeznaczył ogromny budżet na wyprawę do Italii ${ }^{33}$. Wyruszyła ona w 1025 r. pod wodzą protospathariosa eunucha

${ }^{25}$ Por. A. Michel, Die Weltreichs- und Kirchenteilung bei Rudolf Glaber (1044), „Historisches Jahrbuch" 70 (1951) 61-63.

${ }^{26}$ Por. Dvornik, Constantinople, s. 460; tenże, Bizancjum, s. 95. Podobnie sądzi G. Dagron (Ekonomia chrześcijańska i państwo chrześcijańskie, w: Historia chrześcijaństwa, t. 4: Biskupi, mnisi i cesarze 610-1054, tłum. M. Żurowska, Warszawa 1999, 287).

27 Por. Dagron, Ekonomia, s. 287.

${ }^{28}$ Por. Annales Barenses, ad a. 1027, MGH Scriptores V 53; Joannes Scilitzes, Synopsis Historion, ed. I. Thurn, Berlin 1973, 368 [dalej: Skylitzes]; J. Hussey, The Orthodox Church in the Byzantine Empire, Oxford 1986, 119; A. Hohlweg, Byzanz und der Westen. Politische, ideologische, administrative und kulturelle Aspekte, w: Byzanz und seine Nachbarn, ed. A. Hohlweg, München 1996, 102; I.G. Leontiades, Die Westpolitik Basileios II. (976-1025), w: Byzanz und das Abendland im 10. und 11. Jahrhundert, hrsg. E. Konstantinou, Köln - Weimar - Wien 1997, 268. Dwaj ostatni sądzą, że cesarz sam chciał objąć dowództwo nad wyprawą na Zachód. Na temat polityki zachodniej Bazylego zob. F.I. Uspienskij, Istoria vizantijskoj imperii. Period Makedonskoj dynastii (867-1057), Moskva 1997, 445-448.

${ }^{29}$ Por. Leontiades, Die Westpolitik, s. 268.

${ }^{30}$ Por. I trattati con Bisanzio (991-1198), dok. 1, ed. M. Pozza - G. Ravegnani, Venezia 1993, 21-25.

${ }^{31}$ Por. M. Gil, Sicily 827-1072 in light of the Geniza documents and paralel sources, w: Italia Judaica. Gli Ebrei in Sicilia sino all'expulsione del 1492 [ = Atti del V Convegno Internationale, Palermo 1992], Palermo 1995, 110.

32 Por. Leontiades, Die Westpolitik, s. 267.

${ }^{33}$ Por. V. Laurent, L'Église de l'Italie meridionale entre Rome et Byzance à la veille de la conquête normande, w: La Chiesa greca in Italia dall' VIII al XVI secolo, I, Padove 1974, 20. 
Orestesa, jednego z najbardziej zaufanych ludzi cesarza ${ }^{34}$. Katepan Bazyli Boioannes, który na polecenie władcy odbudował fortyfikacje Reggio, otrzymał polecenie przygotowania inwazji na Sycylię ${ }^{35}$. Wkrótce potem wylądował na wyspie i zdobył Messynę ${ }^{36}$. W przeciwieństwie do niego Orestes nie odniósł sukcesów i po klęsce pod Reggio został wkrótce odwołany ${ }^{37}$. Tak zapoczątkowana akcja została przerwana wskutek śmierci władcy. W Kalabrii walki toczyły się do 1027 roku. W ich efekcie przywrócono tam panowanie bizantyńskie $^{38}$. „Basil's final plans had miscarried, but the decision to ignore the east and to intervene in Sicily is indicative of what he had achieved" - napisał Mark Whittow $^{39}$. To jednak dość kontrowersyjna opinia. Cesarz z całą pewnością nie lekceważył sytuacji na Wschodzie, natomiast, podobnie jak jego poprzednicy, nie mógł się pogodzić z pozbawieniem Bizancjum zachodnich prowincji.

Plany wobec Zachodu mogły skłonić Bazylego II do podjęcia negocjacji z papiestwem. Wszak to właśnie na obszarze południowej Italii zderzały się najsilniej wpływy rzymskie i bizantyńskie. Papieże niechętnie patrzyli na stosowanie wschodniej liturgii $w$ istniejących na tym obszarze greckich klasztorach. Powrót cesarstwa na Sycylię nie tylko zaostrzyłby te spory, ale także ponownie postawiłby na porządku dziennym problem jej miejsca w strukturze administracyjnej Kościoła ${ }^{40}$. W tej sytuacji zrozumiała byłaby decyzja władcy,

34 Por. Annales Barenses, ad a. 1027, 53; Skylitzes, 383-384; Georgius Cedrenus, Historiarum compendium, ed. I. Bekker, II, Bonnae 1839, 43, 479, 496, 503 [dalej: Cedrenus]; V. von Falkenhausen, La dominazione bizantina nell' Italia meridionale dal IX all XI secolo, Bari 1978, 64 i 73; Leontiades, Die Westpolitik, s. 267-268; R. Guilland, Les eunuques dans l'Empire byzantin, w: Recherches sur les institutions byzantines, I, Berlin - Amsterdam 1957, 173; V. Laurent, Légendes sigillographique et familles byzantines, III, EO 35 (1932) 335-337; R. Ménager, La „,byzantinisation" religieuse de l'Italie méridionale ( $I X^{e}-X I I^{e}$ s.) et la politique monastique des Normands en Italie, RHE 54 (1959) 8 (datuje jego przybycie do Italii na 1028); M. Whittow, The Making of Orthodox Byzantium 600-1025, Hampshire 1996, 390.

35 Por. J.J. Norwich, Byzantium. The Apogee, New York 1992, 245.

${ }^{36}$ O planach cesarza wspomina Zonaras (Epitome historiarum XVII 9, ed. Th. BüttnerWobst, III, Bonnae 1897, 568); por. L. Bréhier, The Life and Death of Byzantium, transl. M. Vaugham, Amsterdam 1977, 164; Falkenhausen, La dominazione, s. 65; Norwich, Byzantium, s. 245; Whittow, The Making, s. 390.

37 Por. J. Gay, L'Italie méridionale et l'empire byzantin depuis l'avenement de Basile Ir jusqu'à la prise de Bari par les Normans (867-1071), II, New York 1904, 429.

38 Por. Gil, Sicily, s. 110.

39 Por. Whittow, The Making, s. 390.

${ }^{40}$ Przypomnijmy, że w 1. poł. VIII wieku Sycylia, południowa Italia i Illyricum zostały mocą cesarskiej decyzji wyjęte spod jurysdykcji biskupa Rzymu i podporządkowane Konstantynopolowi. Na temat przyczyn, okoliczności i daty tego wydarzenia zob. M.V. Anastos, The Transfer of Illyricum, Calabria and Sicily to the jurisdiction of the patriarchate of Constantinople in 732-733, w: Silloge bizantina in onore S. G. Mercati, Roma 1957, 14-31 [przedruk w: M.V. Anastos, Studies in Byzantine Intellectual History, London 1979, art. IX, 14-31]; V. Grumel V., L'Annexion de l'Illyricum Oriental, de la Sicile et de Calabre au patriarcat de Constantinople, RSR 40 (1952) 191-200. 
by podjąć próbę uporządkowania stosunków z Rzymem. Pojednaniu sprzyjać mógł fakt, iż sycylijscy Arabowie byli wspólnym wrogiem dla papiestwa i Bizancjum. Dlatego należy zgodzić się z tymi uczonymi, którzy, mimo braku potwierdzenia informacji Glabera przez źródła wschodnie, są skłonni sądzić, że poselstwo Bazylego w istocie zostało wysłane na Zachód. Dodajmy, iż Glaber około roku 1028 odbył podróż do Italii u boku Wilhelma, opata Dijon. Mógł zatem pozyskać informacje od osób bliskich wydarzeniom.

Inną sprawą jest, czy w pełni można zaufać kronikarzowi w sprawie zawartości bizantyńskich propozycji. To, że biskup Konstantynopola żądał dla siebie prawa do tytułu patriarchy ekumenicznego, wydaje się całkowicie oczywiste. Jego poprzednicy używali go od ponad pięciuset lat i nie było żadnych powodów, by Eustacjusz miał z tego rezygnować. Ograniczenie aspiracji patriarchy do obszaru cesarstwa też jest prawdopodobne, bowiem mieści się całkowicie w tradycji. Jak wspomniano powyżej, tak właśnie rozumiano sporny tytuł w VI wieku.

Znacznie mniej prawdopodobne jest natomiast, iż Bizantyńczycy zabiegali o zgodę papieża na używanie tytułu patriarchy ekumenicznego. Podkreślić trzeba, że na Wschodzie wcale nie negowano całkowicie papieskiego prymatu. Zarówno cesarz jak i patriarchowie Konstantynopola respektowali pierwszeństwo biskupa Rzymu, lecz gotowi byli uznać jedynie jego prymat honorowy, nie zaś realną władzę. Nie chcieli zgodzić się na bezpośrednią ingerencję w sprawy patriarchatu konstantynopolitańskiego ${ }^{41}$. Nigdy wcześniej nie pytali papieży o zgodę na nazywanie się „ekumenicznymi” i bardzo wątpliwe, by nagle postanowili to uczynić na początku XI wieku. Niewykluczone natomiast, że cesarscy posłowie mieli wyjaśnić papieżowi, jaki sens jest nadawany spornemu tytułowi na Wschodzie. Moźliwe także, iż poselstwo Bazylego przy-

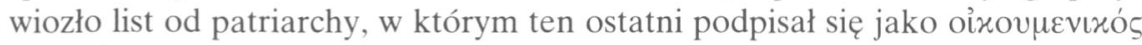

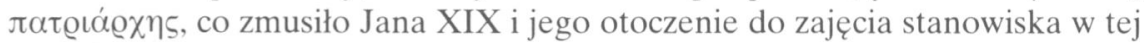
sprawie.

Twierdzenie Rodulfa, iż posłowie zabiegali o zgodę papieską, łatwo wyjaśnić jego głębokim przekonaniem, że tak powinno było się stać. Idea, że wszystkie decyzje w Kościele powszechnym muszą uzyskać akceptację Rzymu, mieści się całkowicie w tradycji zachodniej. Grzegorz Wielki pisał: „sine apostolicae sedis auctoritate atque consensu nullas, quaeque acta fuerint, vires habeant" ${ }^{\text {"42. }}$. Sądził (błędnie), iz sobór w Chalcedonie przyznał tytuł patriarchy ekumenicznego biskupom Rzymu ${ }^{43}$. Równocześnie podkreślał, że rezygnuje z tego prawa,

${ }^{41}$ Por. Dvornik, Bizancjum, s. 72. Autor ten podkreśla, iż uznawana na Wschodzie zasada pentarchii nie oznaczała uznania absolutnej równości wszystkich patriarchów (tamże, s. 75); zob. też Schatz, Prymat papieski, s. 97-99.

42 Epistolae IX 157, CCL 140A, 715.

${ }^{43}$ Por. Epistolae V 37; V 41; VIII 29 i in. Faktycznie jedynie papieża Leona Wielkiego nazwano biskupem ekumenicznym w dokumentach soborowych. 
by nie umniejszać prerogatyw innych biskupów. Chociaż formalnie stanął na stanowisku, iż żaden biskup nie może nazywać się ",powszechnym" "44, de facto był przekonany o zwierzchności Rzymu nad innymi biskupami, nie wyłączając pozostałych patriarchów. „Nam de Constantinipolotana Ecclesia quod quis eam dubitet sedi apostolicae esse subjectam" - napisał Grzegorz ${ }^{45}$. Rodulf Glaber nie musiał znać całości dzieł Grzegorza I, ale z całą pewnością jego myśl nie była mu obca. Jeśli wierzyć benedyktyńskiemu kronikarzowi propozycje strony bizantyńskiej spotkały się z gwałtownym oporem na Zachodzie; wręcz wywołały skandal w Italii ${ }^{46}$. Jego wyrazem był list skierowany do papieża przez Wilhelma z Volpiano, opata Dijon ${ }^{47}$. Rodulf przytacza jego tekst w całości. Fakt, iż kronikarz znał osobiście autora, bowiem w kierowanym przez niego klasztorze spędził część swego życia ${ }^{48}$, przemawia za uznaniem pisma za autentyczne $e^{49}$.

Już w nagłówku listu Wilhelm dał wyraz swym poglądom na rolę Stolicy Apostolskiej, podkreślając, że rzymski tron biskupi jest z Bożej łaski i dzięki świętemu Piotrowi najwyższym w świecie chrześcijańskim ${ }^{50}$. Następnie podkreślił, iż dawna władza cesarzy rzymskich należy obecnie do stolicy Piotrowej, zaś żądania Greków, o których usłyszał (nie wiemy niestety od kogo), są wyrazem próżnej żądzy chwały (cenodoxia ${ }^{51}$ ). Poglądy te były bliskie stanowisku samego kronikarza. Glaber określił je jednoznacznie już w tytule odnośnego fragmentu swej Kroniki: „De universale Ecclesiae a Constantinopolitanis iniuste requisita” [podkr. moje - T.W.] ${ }^{52}$. Dalej określił żądania Greków jako przejaw „,cesus amor habendi”. Jego ocena nie różni się zbytnio od opinii Grzegorza Wielkiego, który krytykował patriarchów za używanie „stulto ac superbo vocabulo" 53 , a ich zachowanie określał jako „nova superbia" ${ }^{54}$, ,ambitioso desiderio" ${ }^{5}$. Podkreślał, iż: „quisquis se universalem sacerdotem vocat, vel vocari desiderat, in elatione sua Antichristum praecur-

${ }^{44}$ Por. Epistolae VIII 29.

45 Epistolae IX 26, CCL 140A, 587.

46 Por. Glaber, Cronache IV I, 2.

${ }^{47}$ Por. Glaber, Cronache IV I, 3. Hugo z Flavigny (Chronicon Virdunense II 17) wśród przeciwników uznania pretensji Konstantynopola wymienia też Ryszarda z Saint-Vanne.

${ }^{48}$ Rodulf napisal żywot Wilhelma z Volpiano, por. Vita domni Willelmi abbatis, ed. N. Bulst, neue Edition nach einer Handschrift des 11. Jahrhunderts (Paris Bibl. Nat., lat. 5390), w: „Deutsches Archiv" 30 (1974) 450-487.

${ }^{49}$ Autentyczność tego listu neguje Anton Michel (Die Weltreichs- und Kirchenteilun, s. 5658), z czym nie zgadzają się włoscy wydawcy dzieła Rodulfa (Glaber, Cronache, s. 343, przypis 24).

${ }^{50}$ Por. Glaber, Cronache IV I, 3: „Gratia Dei et reverentia beati apostolorum principis Petri sedium in orbe excellentissima".

${ }^{51}$ Por. tamże.

52 Tamże IV I, 2

53 Epistolae V 44, CCL 140, 330.

54 Tamże V 41, CCL 140, 323.

55 Tamże V 44, CCL 140, 329. 
rit”56. Odwoływał się do tradycji, której przeciwstawiał „nowy” i „świecki” tytuł przyjęty przez patriarchę ${ }^{57}$. Tych ostatnich argumentów nie znajdziemy u Rodulfa Glabera. Jest to całkowicie zrozumiałe. Skoro dla niego było oczywiste, że papież jest biskupem powszechnym, nie mógł atakować tytułu, jako takiego. Jego niechęć kierowała się tylko przeciw nieuprawnionemu, jego zdaniem, żądaniu Bizantyńczyków, by przysługiwał on także patriarsze Konstantynopola.

Nie wiemy, jaka była reakcja Jana XIX na złożoną przez Bazylego II propozycję. Wielu uczonych sądzi, iz papież gotów był zaakceptować żądanie Bizantyńczyków, lecz ustąpił wobec stanowczej, negatywnej reakcji biskupów i opatów ${ }^{58}$. W źródle brak jednoznacznych dowodów, że właśnie tak było. Powyższa opinia została sformułowana najprawdopodobniej w oparciu o fakt, że Rodulf Glaber pisząc o audiencji greckiego poselstwa u papieża podkreślił, że żądza pieniądza ma w Rzymie głębokie korzenie ${ }^{59}$. Sugerował też, iż niektórzy Rzymianie byli gotowi zawrzeć porozumienie i szukali sposobu, by zrobić to po cichu ${ }^{60}$. Nieco dalej zamieścił bardzo krytyczną opinię o papieżu Janie XIX, który zawdzięczał zdobycie tronu papieskiego symonii ${ }^{61}$.

Nie rozstrzygając, czy niechętna Janowi XIX tradycja, zgodnie z którą gotów był kupczyć uprawnieniami Stolicy Apostolskiej, jest sprawiedliwa, nie ulega wątpliwości, iź środowisko reformatorskie w Kościele starało się wywierać wpływ na jego decyzje. W każdym razie Bizantyńczycy odjechali nie uzyskawszy nic w kwestii tytułu patriarchy ekumenicznego.

Sprzeciw Rodulfa Glabera wobec zwyczaju nazywania patriarchy Konstantynopola „ekumenicznym” pozwala nam dostrzec zmiany, jakie zaszły na przestrzeni kilku stuleci na Zachodzie w pojmowaniu zakresu władzy papieża nad Kościołem powszechnym. Jak pamiętamy, Grzegorz Wielki był wprawdzie przekonany, iż z racji apostolskiego, Piotrowego, pochodzenia, biskupstwu rzymskiemu przysługują szczególne prerogatywy, ale równocześnie miał opory przed akceptacją przymiotnika „ekumeniczny” w odniesieniu do swego urzę$\mathrm{du}^{62}$. W tekście jedenastowiecznego kronikarza nie znajdziemy już podobnych

56 Tamże VII 30, CCL 140, 491.

${ }^{57}$ Por. tamże V 37, CCL 140, 308. W innym miejscu nazwał tytuł biskupa powszechnego „haniebnym” (Ep. VII 31), „pysznym” (Ep. VII 28), a o tym, który pragnie tak się nazywać napisał, że uprzedza Antychrysta (Ep. VII 30).

58 Por. Dagron, Ekonomia, s. 287; zob. także Dvornik, Bizancjum, s. 96; F. Seppelt K. Löffler, Dzieje papieży, I, Warszawa 1995, 186 (reprint wydania z 1936 r.).

59 Por. Glaber, Cronache IV I, 2.

60 Por. tamże.

${ }^{61}$ Por. tamże IV I, 4. Wypomniał mu też, iż będąc osobą świecką, po śmierci poprzednika, swego brata, Benedykta VIII, wbrew prawu kanonicznemu przyjął wszystkie święcenia w ekspresowym tempie.

${ }^{62}$ Przypomnijmy raz jeszcze jego list do Eulogiusza, patriarchy aleksandryjskiego (Ep. VIII 29) w którym pisał, że do nikogo nie powinno się zwracać, jako do „powszechnego”. 
wątpliwości. Trudno się temu dziwić. Wszak zaledwie pięćdziesiąt lat później papież Grzegorz VII napisze w 1075 r. w Dyktacie papieskim, iż tylko biskup Rzymu może być nazywany „powszechnym”.

\section{ELEVENTH-CENTURY ECHOES OF THE ARGUMENT ABOUT THE TITLE OF ECUMENICAL PATRIARCH}

(Summary)

Chronicler Rodulf Glaber has written about a Byzantine legation to Rome in ca. 1024. The envoys were to demand consent, on behalf of the patriarch and the emperor, to use the title ecumenical by the bishop of the Empire's capital city. Glauber's account does not seem reliable. Still, despite some scholars' doubts, it is believed that the legation really took place. Far-sighted plans of restoring influence in Italy and Sicily may have made Emperor Basil II take up negotiations with Rome.

Yet, it was unlikely for the patriarch to seek the Pope's consent to use the title that his predecessors had used for five hundred years. Even in the era of a fierce argument about that title, which took place during the pontificate of Gregory the Great (590-604), patriarchs did not find the Pope entitled in any way to decide about it.

It is possible that the envoys brought a letter, signed by patriarch Eustacius as ecumenical patriarch, which forced Pope John XIX to express his opinion about it. According to Glauber's account the demand of the Greeks would rouse indignation in the West and consequently the legation left Rome without success.

62 Por. A. Weiss, Dictatus papae, EK III 1302 (podana też literatura); tekst wyd. E. Caspar, MGH Ep II 201-208 oraz W. Semkowicz, w: Teksty źródłowe do nauki historii w szkole średniej, z. 15, Warszawa 1924, 8-9. 